Article

\title{
Manchester Civil Justice Centre: Procuring and Managing an Institutional Building with a Mixed Mode Ventilation System-A Case for Post-Occupancy Evaluation
}

\author{
John Napier \\ Department of Architecture, University of Lincoln, Brayford Pool, Lincoln, LN6 7TS, UK; \\ E-Mail: jnapier@lincoln.ac.uk; Tel.: +44-7226-7148 \\ Received: 1 February 2013; in revised form: 14 March 2013 / Accepted: 29 March 2013 /
}

Published: 11 April 2013

\begin{abstract}
Manchester Civil Justice Centre is a striking contemporary 14 storey court building which has won awards for many different aspects of its design, construction and sustainability. From November 2002 to July 2005, the author was a key member of Denton Corker Marshall's London project team having responsibility for key areas of design development, integration of technology and sustainable design including the East elevation's "environmental veil". This paper tracks the procurement of the building, describing its low energy features and their performance in practice. The paper reviews the low carbon elements of the design (daylight and natural ventilation systems) in the context of similar buildings and the buildings operational performance. The building has a mixed mode ventilation system which is managed centrally; the paper describes the ongoing relationship between the Facilities Management and the building's users and their expectations of comfort and offers an explanation as to why the building's energy performance is not as good as predicted at design stage. A case is made that this building is a significant example of low energy design and would form a good example for a detailed Post Occupancy Evaluation. The energy performance of the building could be studied in more detail to encourage the users (judges, staff and the public) to improve the building's energy performance and to share knowledge within the construction industry. Institutional and commercial barriers to the more mainstream adoption of Post Occupancy Evaluation are discussed with respect to the Manchester Civil Justice Centre.
\end{abstract}


Keywords: mixed mode ventilation; low carbon design; building performance; public procurement; facilities management; Manchester civil justice centre; barriers to post-occupancy evaluation

\section{Why Review, in 2012, the Manchester Civil Justice Centre?}

Manchester Civil Justice Centre (MCJC) is a tall urban building (14 storeys, $80 \mathrm{~m}$ high), completed in 2007, with low energy, daylight and natural ventilation systems embedded within the design. The building has been published widely and has received numerous awards for design, sustainability and construction quality [1]; it was shortlisted for the Stirling Prize in 2008 and included in Blueprint's 10 Best Buildings of the 21st Century [2] .The building achieved a rating of BREEAM Excellent (Building Research Establishment Environmental Assessment Method) at design stage. This review focuses on the environmental systems which sit within and underpin the project and how the management context of their operation influences their performance.

Low energy buildings (and especially those studied in Post Occupancy Reviews) up to that time tended to be on green field sites or in business parks where the buildings could be more easily oriented to sun and prevailing wind with fresh air with limited pollution. These buildings, however, would typically be accessed by individual cars; occupants transport emissions on their journey to work add significantly to an overall Carbon footprint of the complex, negating somewhat the good intentions of low energy design. An example of this would be the Arup Campus, in Solihull designed by Arup Associates [3]. The Manchester building, however, sits in Spinningfields, a new urban pedestrian precinct between the River Irwell and Deansgate in the centre of Manchester, the master plan of which is still evolving with the Civil Justice Centre having set a precedent for taller buildings.

Low energy buildings in addition are typically commissioned by their owners and future occupants. Manchester Civil Justice Centre, however, was procured under the Private Finance Initiative by the (now) Ministry of Justice (The Court Service) who arranged a design competition where Denton Corker Marshall (Architects) and Connell Mott MacDonald's (Structural, Mechanical and Electrical Engineers) proposal was chosen ahead of lower rise designs by the only two other shortlisted teams led by Richard Rogers Partnership and Pringle Richards Sharratt to a brief prepared for the Court Service which had strong and clear sustainable goals written into the project from the beginning. These included BREEAM targets, the use of natural ventilation and indoor air quality.

The high political profile of the project helped to ensure a favourable budget and goodwill from the various parties as the project and its design team navigated the complexities of working for in turn, the Ministry of Justice (competition stage), Allied London Properties, the landowner and developer (design and documentation stages) Bovis Lendlease, Management Contractors (tendering and construction stages). In addition Gardiner and Theobald acted as Project Managers. At critical handover stages a comprehensive document was prepared setting out the agreed design and specification at that stage and the ground rules for the development of the next stage. An early milestone was the completion of the "Agreement to Lease" between the Court Service and the Developer which defines not only the building design and its specification, but also the terms of the 
building management services over the lease period. The next landmark was the completion of the "Employer's Requirements" which defined the building design to be constructed by the Contractor. At these stages the Court Service, through their advisers, confirmed their agreement to the project.

The building's future users, as far as they were known to exist, were kept at a distance from the design team. This helped speed the design development process as there was a strong level of agreement to proceed with the main building layouts while some details were being reviewed and adjusted.

As a response to the environmental brief, two key features of the low energy design, the environmental veil, an east facing layered facade system, and the natural ventilation system are incorporated within a strong contemporary design both in concept, detail and materials. This is done discretely and elegantly without the explicit architectural expression which might be seen in the low energy design of, for example the Lanchester Library building for the University of Coventry [4]. It is these features of MCJC which will be studied more closely in this paper.

Although this is a large bespoke building it is thought that there are potential lessons in low energy design for more generic buildings in the commercial and educational sectors.

\section{The Approach to This Review of the Building in Use}

This review focuses on the management, performance and operation is use of the environmental features of the building from the perspective of the author's involvement in the design stage of the project.

The review was initiated by the author, who, five years after leaving Denton Corker Marshall, has an academic role in a School of Architecture, and saw value in evaluating this project with the critical distance brought by both time and a new role within architectural discourse. Help in preparing it has come from the Architects, the Engineers and the Facilities Managers, albeit without either party wishing to open the building's operation and performance to a very detailed scientific scrutiny. Discussions with Denton Corker Marshall's and Connell Mott MacDonald's Directors helped clarify the author's understanding of the design and developments post Practical Completion.

The research intention for this paper, after some preparation, and considering the size and complexity of the building, was to meet and interview the building's Facilities Manager together with a site inspection, and following this assess the most promising lines and methods of enquiry regarding user satisfaction and building performance. A very productive and informative meeting took place with the building's Facilities Manager, an experienced and knowledgeable person who has been in post since the project's handover in 2007, together with a site inspection of the key areas of the building described. This interview was led by questions derived from the methodology of Post Occupancy Studies [5]. The interview was wide ranging and based on questions formulated from a clear architectural knowledge of the building's systems.

After some deliberation, a series of detailed questions and requests for information was formulated for the Facilities Manager and the contractor who installed and manages the Building Management System as a follow up to that meeting. It was hoped that building performance data could then be compared in some detail with forecast performance from the Design Engineers, Mott MacDonald. However the Facilities Manager has not been able to engage with that more detailed level of enquiry or 
encourage (as the principal contact for this type of enquiry) contact with other personnel at Manchester Civil Justice Centre.

Commercial confidentiality has limited the information which was to be made available. This confidentiality is understandable because of the complex background of the Agreement to Lease between Developer and Client and the highly charged public profile of the scheme.

Post-occupancy evaluations can serve a variety of purposes depending, in part, on which stakeholder is paying for the study and the extent to which the information is shared. Indeed there are issues as to who should pay for such a study. There have been moves to include this type of survey in the normal services provided by a Design Team; this has fallen out of favour over the years.

The Design Team are most likely to benefit, in terms of clarifying the extent to which their ideas have been successful in practice, in the quest for continuous improvement of their knowledge base. A number of highly regarded practices agree with their Clients that at appointment stage that they will do this. Others, more defensively, "never go back" in fear of being drawn into grey areas of who is responsible for responding to the findings of the study, and the potential professional liabilities which may be involved. For the design team, design solutions in one market sector may have application in another market sector and may not be specific to that building type. Features which are built for the first time within that practice (or within the industry) can be studied and lessons learned for future projects.

For Clients benefits can be for the immediate building or as part of a continuous programme of building commissioning. Increases in building and staff performance may arise by ironing out "trouble spots" not discovered in a more contractual commissioning process. For the Ministry of Justice (and also the Design Team) benefits would have occurred if a follow on project, the Birmingham Civil Justice Centre, had proceeded beyond the design stage. Risks can occur in opening up grievances of staff and building users and grey areas could surface in a Private Finance Initiative project between the public body and their private service provider.

If the evaluation is to be made or to become public, all parties will be concerned for their reputations, which may or may not be enhanced by the outcomes. These points regarding the benefits and barriers to Post-occupancy evaluation are discussed in more detail in separate papers by Zimmerman, Hadjri and Riley [6-8].

For the author, the study provided an opportunity to be reassured of the success of those parts of the project which are "industry standard" and learn more of those parts of the project which are more innovative and in a sense "prototypical", this being mainly the mixed mode ventilation system.

The outline of the building's performance given by the Facilities Manager at the interview is supported by the information presented to the public in the Display Energy Certificates, both current (display prominently in the entrance hall) and previous. The opportunity was taken to compare this data with publicly available data from buildings of similar scale, context and ambition, and in some cases confidentiality; the intention is to extend the range of buildings which can be studied post occupancy, even if this cannot be at great depth. Some of comparable buildings are referred to in the following "Precedents" section of the paper.

The author was a key member of the architectural design team in Denton Corker Marshall's London office (the main office is in Melbourne where the design had been initiated and from where it continued to be overseen) from 2002-2005, helping develop the concept and working through the 
design development and detail stages. Design development was led from the London office with a Senior Architect posted from Melbourne for the duration of the project. Digital drawings and video conferencing supported an International project team. Key design decisions would be made or confirmed by the Partners in Melbourne. These stages are often rushed but in this case were very important in embedding the innovative features in a building which was subject to the commercial scrutiny of "value engineering" and the contractor's approach to build-ability through these stages. The author worked as a technical coordinator (among other roles) linking the work of the engineering systems to the evolving architectural development and was keen to see how these systems are working in practice. The author was particularly involved with the design of the East facade and environmental veil and the integration of the "Light Air Ducts" within the development of the interior of the building. As part of discussing the building in use the tension between satisfying user comfort criteria and driving down the energy consumption and carbon emissions became more apparent. MCJC is a mixed mode building and the option is available for prioritizing user comfort over energy (or vice versa) in the operation of the building. These priorities may be brought together over time. The idea that the completion of the construction of a building is just the beginning of the life of that building has been found valuable in putting lessons of the project into perspective [9].

In addition the relative merits of low carbon performance and occupant satisfaction are contested. The need to reduce heating and air conditioning loads and hence energy costs and carbon emissions was apparent to the Client at briefing stage. In addition the amenity of fresh air, natural ventilation and daylight was considered to be important to the health and productivity of a building's users and occupiers, the total salary costs of whom significantly outweigh the costs of the energy to support their activities and indeed the capital costs of the building [10].

The review is based mostly on the information and experience shared with the author by the Facilities Manager, Chris Hosker, in a meeting and site visit on 14 September 2012. Chris Hosker is in day to day contact with everybody in the building from the Judges, the Ushers (who deal with the court room users and the public) and in particular the Building Engineers. The feedback from the site helped contextualize the understanding of the building's systems in practice.

Three main factors determine the energy use in a building: design and construction, occupant activity, and operation and maintenance. In the case of a centrally managed heating and ventilating environment the role of the Facilities Management Team in setting (and agreeing with the occupants) the parameters for these systems is of greater importance than in a building which allows more occupant choice on a room by room basis.

The role of Facilities Management teams in helping achieve predicted performance does not appear to be sufficiently recognised at present. This paper looks at building performance from the view of a Facilities Manager and so offers a fresh perspective on energy efficiency in practice.

\section{Precedents}

\subsection{Low Energy Buildings in Urban and Other Settings}

The commissioning of low energy buildings in the commercial and institutional sectors in the UK is still, in 2012, not mainstream practice, although good examples of practice are regularly published in 
architectural and other building journals. Further education projects have been more frequently the pioneers of low energy design and fewer buildings in compact urban areas have low energy credentials (apart from the reduction of associated transport costs). Further education projects are more likely to be the subject of Post-occupancy reviews, perhaps because the Clients are more able to take a longer time view of their buildings. Of the thirty buildings reviewed by Baird, ten or less could be described as located in compact urban settings [11]. In addition urban commercial projects are held back by the frequent separation of interests of developer and future users.

Manchester Civil Justice Centre, by virtue of its procurement route is a commercial building, developed and owned by Allied London Properties and leased back to the Ministry of Justice. During the design's development the culture of commercial building development was a reference point for the Developer Client, the Project Managers and the Management Contractor. Indeed consideration of the future conversion to office accommodation at the end of the lease was a part of the developer's criteria in evaluating the ongoing design.

Office development in UK is strongly influenced by US practice where shell and core projects maximizing land value (often in a prime location) are developed for generic users who will lease space from a financial institution The balance between first cost and costs in use can suffer in this market relationship [12]. Deep plan, highly glazed (although now often with solar shading devices) air conditioned buildings are the typical product of the UK Development industry, although narrower plans with natural ventilation through atria are common on Business and Science Park developments out of town. Green credentials have recently become of importance at planning stage and when marketing the project to occupiers. The use of the BREEAM system of rating buildings at design stage has become commonplace within this market. The incentive to follow up this new approach once an occupier is in place is less apparent to date.

The European model of commercial property development relies more frequently on bespoke procurement by individual companies. The design there is influenced to a greater degree by considerations of operating costs, user preferences and productivity. Office buildings in Germany have for long incorporated narrow plans, user controls of windows, blinds and ventilation systems together with low energy design concepts. High rise examples of this include the 53 storey Commerzbank in Frankfurt by Foster and Partners [13] (completed 1997) and the 22 storey GSW offices in Berlin by Sauerbrauch Hutton (completed in 1999) are good examples. The use of double skin facade construction has its beginnings in this German stream of office procurement [14].

Ken Yeang has been a pioneer of green sky scrapers with many proposals and completed projects in Asia in particular and further tall buildings with these criteria have been conceived since this project, including the Pinnacle by KPF in the City of London [15].

\subsection{Court Buildings and Institutional Buildings}

Manchester Civil Justice Centre with its 47 court rooms is the largest UK court building since the Royal Courts of Justice in the Strand in London, designed by Edmund Street in a Gothic style and completed in 1892. Smaller regional court buildings had been commissioned across England before this project, many of them presented in traditional architectural styles and without particular 
environmental ambitions in their briefing. A notable exception was the Truro Crown Court by Evans and Shalev. The Rotherham Magistrates Court is the subject of a Post-occupancy evaluation [16].

Richard Rogers Partnership had completed the Bordeaux Law Courts in 1998, a building pioneering in both its architecture and environmental design and subsequently completed the 32 court Antwerp Law Courts in 2005. "As well as the functional and technical requirements, wider objectives of the project included rendering the workings of Justice more 'transparent', giving dignity to the process" [17]. The use of glass to convey this political message is also quoted by Denton Corker Marshall for MCJC and by Foster and Partners in their design for the Berlin Reichstag and London County Hall.

An institutional building with a comparable political profile is Portcullis House, the Parliamentary offices designed by Hopkins and Partners above Westminster underground station [18]. This features bold ventilation chimneys visible both within the facade and at roof level.

The environmental precedent, however, for the project appears to be the BRE Environmental Office by FCB Studios with its narrow linear arrangement, cross ventilation and solar screening and solar chimneys (which were an early part of the design for MCJC's environmental veil) [19]. Earlier architectural precedents in the field of Law Court design include The High Court at Chandigarh by Le Corbusier which for all its imposing presence houses just nine Courtrooms.

David Chipperfield's subsequent projects for the Barcelona City of Justice, 2009 and the Salerno Palace of Justice Italy both have a much reduced window to wall ratio and a return to a more traditional and forbidding aesthetic for legal buildings [20].

\section{Key Features of the Environmental Design and Its Evaluation}

The building is a tall linear bar with longer elevations facing west (the Atrium) and east (the "environmental veil"). Projecting fingers of different lengths with "Mondrian" style inner elevations provide striking terminations of the block visible in longer views on Bridge Street and within Spinningfields. Each of the main facade systems can be described as double skin facades (Poirazis, 2004) with different advantages; both architectural and environmental (see Figure 1) [14].

The 10 storey Atrium provides an impressive public room for the visitors to the building; from here they can see the balconies of the 10 court room floors and their waiting areas. Suspended above the atrium are "Pods" which provide additional waiting and consultation spaces.

Floors 6-10 have larger court rooms where the floor to floor height is increased from the typical $4.4 \mathrm{~m}$ to $5.6 \mathrm{~m}$. On these levels the opportunity is taken to introduce a clerestory which is matched by a "Light Air Duct" (see Figure 2). On the eastern side of the courtroom the light air duct receives daylight from the east wall (and its light shelves) whereas on the west side daylight is reflected through from the Atrium. The court rooms in the lower floors also receive light at high level although without the addition of these "Light Air Ducts". 
Figure 1. The Building from the North East. Atrium to the right (West), Environmental veil (East) to the left.

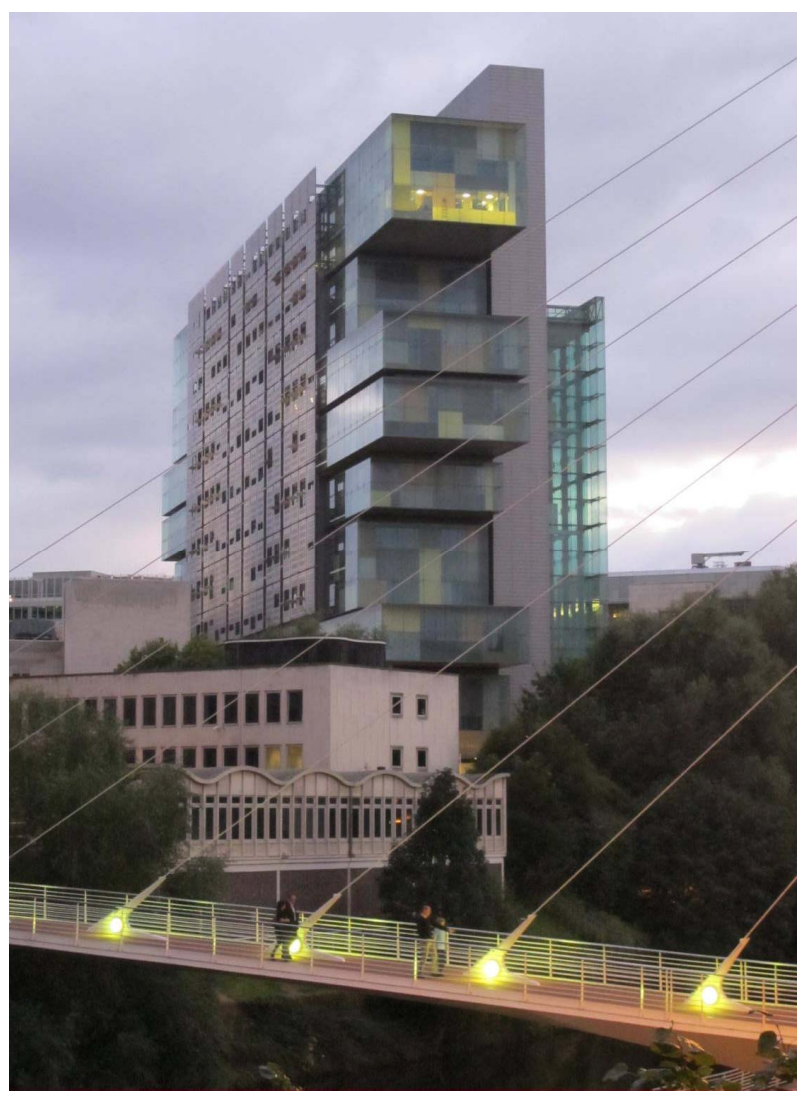

Figure 2. Court Room Floor Plan (Upper Level).

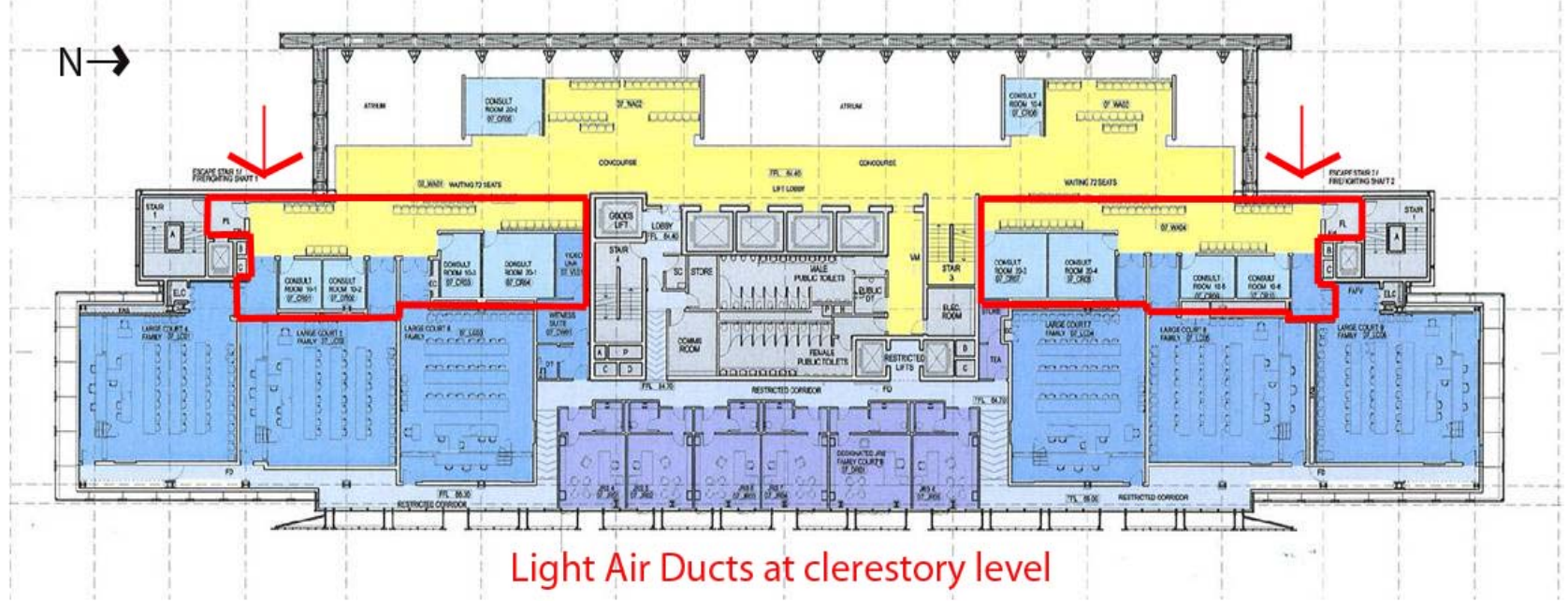

\subsection{The East Wall and the Environmental Veil}

The middle section of the east elevation is screened by a system of aluminium panels with a variety of positions of the following elements: open area/perforated metal panel of different layouts/light shelves. This has been called the "environmental veil" since the competition submission.

This screens a robustly functional arrangement of windows both open-able and fixed at high and at low level, solid spandrel panels and ventilation extract grilles. The glazing percentage of this curtain 
wall is approximately $40 \%$, which helps control both the heating and cooling loads of the building in the manner of a more traditional building. The accommodation behind the east wall comprises principally the staff corridors abutting the court rooms and the Judges Retiring Suites. The divide between these two types of accommodation happens at different positions on each floor contributing to the apparent randomness of the design (see Figure 3).

Figure 3. View of "Environmental Veil" (East facade).

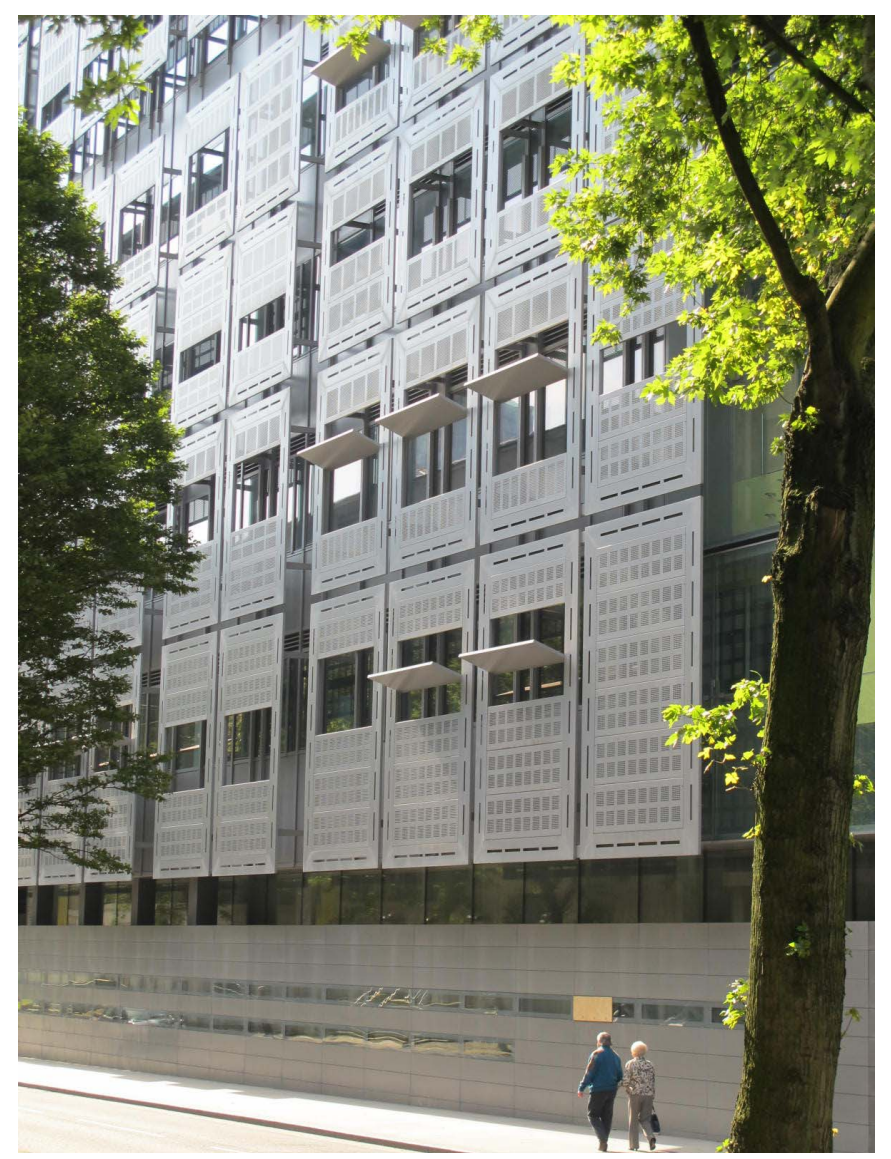

The day lighting of the internal courtrooms is enhanced by a series of light shelves in the environmental veil which bounces light from the azimuth (the brightest part of the sky) into the ceiling of the court room in addition to the shelf above the staff corridor in the taller floors. Windows for light and view are provided to the staff corridor as well as high level glazing. In the taller floors (levels 6-10) an additional light shelf with a reflective surface is provided above the staff corridor. This reflecting system when modeled at design stage was deemed to provide a valuable contribution to daylighting a significant part of the courtroom interior (see Figure 4).

The Judges Retiring Suites are protected from overheating by having a modest glazing ratio and being screened from low angle and diagonal sun by the veil panels. A combination of a horizon level panoramic view through clear openings in the veil and a downward view of the city below was provided for each room (see Figure 5). These rooms do not have air conditioning, this was a condition of the brief; opening windows and radiators are the environmental provision for these cellular office rooms. 
Figure 4. Cross Section showing natural ventilation paths and Light Air Ducts (Blue arrows: Fresh Air In, Red arrows: Exhaust Air).

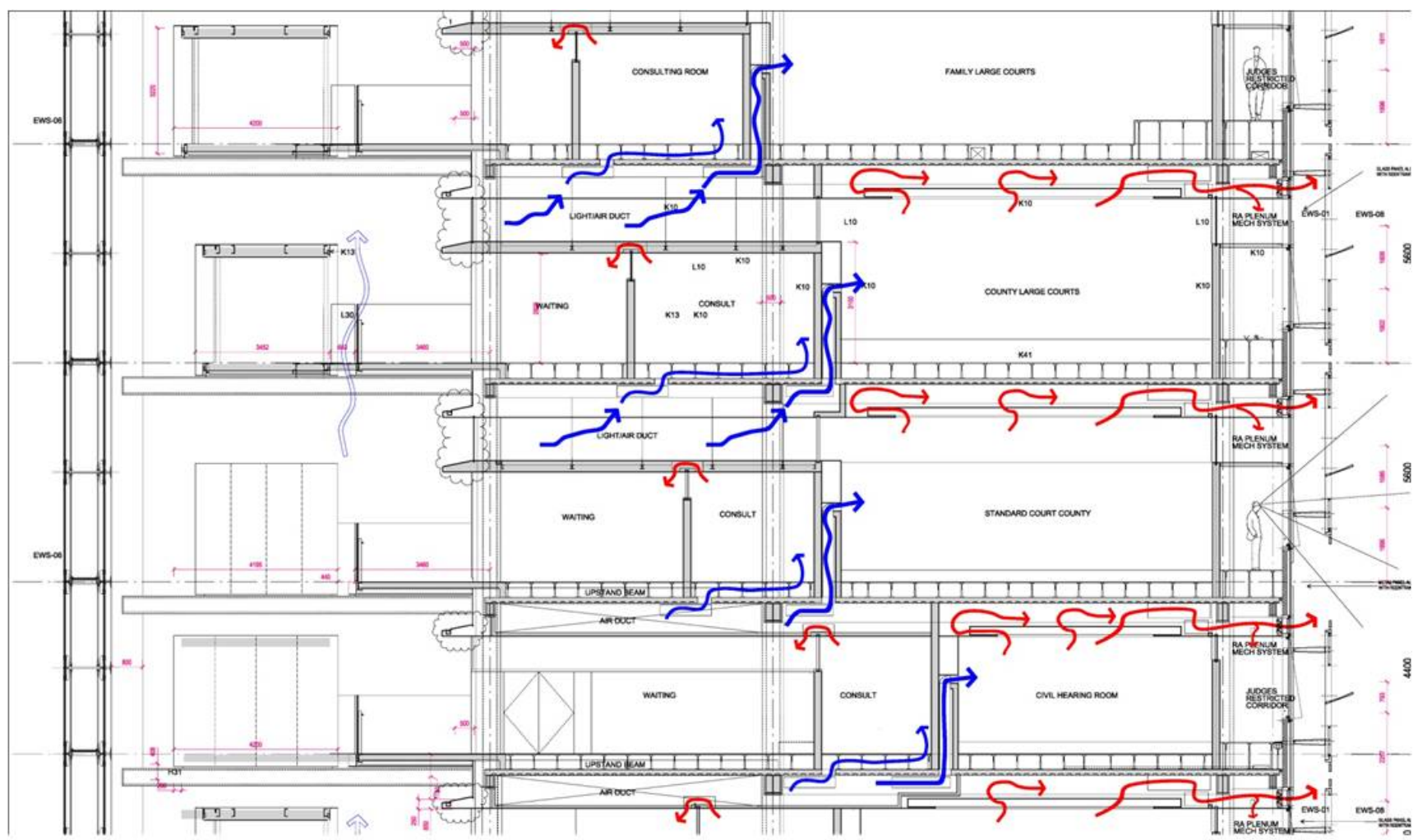

Figure 5. Judge's Retiring Suite.

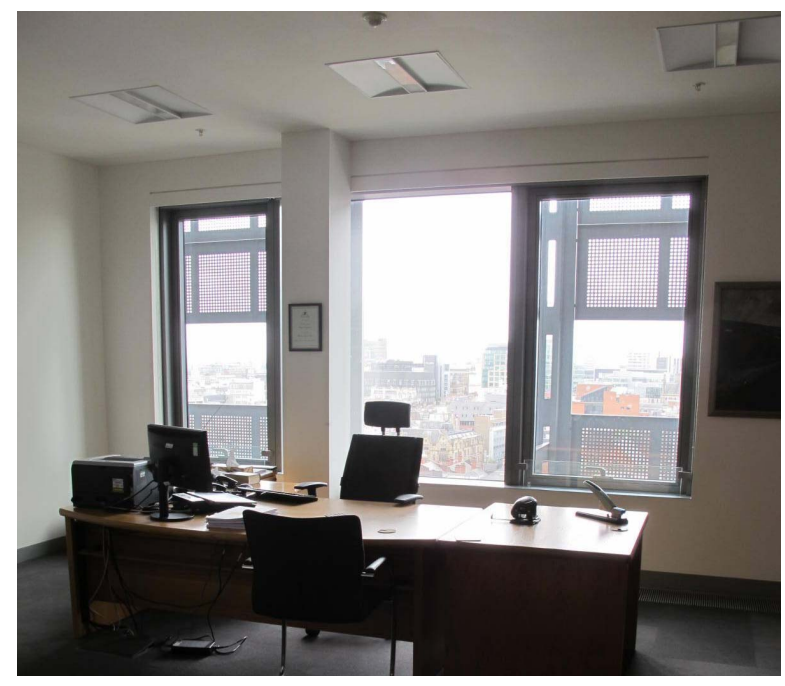

Together the two facade layers with the varying accommodation behind them provide an intriguing visual complexity to the large facade expanse and contribute to the management of solar heat, glare and daylight enhancement.

\subsection{Mixed Mode Ventilation and Light Air Ducts}

The principal court areas and consultation rooms are served by a mixed mode ventilation system. This allows for natural ventilation and fresh air, except when climate conditions or a high level of 
occupancy locally are unfavourable for this, in which case back up comfort cooling or heating is available. The mechanical system's supply air is ducted within a raised floor zone with outlets in the floor panels. The natural system's supply air is fed horizontally at high level in the floor below in a different way for larger courts (which have a 'Light Air Duct) than for smaller courts (which have only an Air Duct).

Larger court rooms are located on levels 6-10 which have an increased floor to floor height. A clerestory space above the waiting area, small rooms and lobbies allows for both light reflection from the atrium into the adjoining courtrooms and fresh air supply from the ends of the building to the courtrooms in the floor above (see Figures 6-8). The ducts are approximately $6 \mathrm{~m}$ deep $\times 20 \mathrm{~m}$ long $\times$ $1.2 \mathrm{~m}$ high with reflective floor and ceiling surfaces. They are accessible as crawlspaces for cleaning and maintenance. These have been called the "Light Air Ducts".

In the Lower Court room floors (levels 3-5), the air supply route described above takes place in a plenum above a conventional plasterboard ceiling. In this case it is an Air Duct only.

In both cases air passes through an acoustic baffle and a fire damper at floor level and is discharged at chest level into the court room through discreet slots in a double wall system. This is planned to avoid drafts being experienced in colder weather. The provision of acoustic baffles is required to avoid sound transfer from room to room and floor to floor; Sandy Brown Associates supported the design team in the acoustic design of the building, which was especially onerous because of both the confidentiality of legal proceedings and the intricacies of the natural ventilation air paths. In the Facilities Manager's view the acoustic separation throughout the building is very effective.

Extract of stale air is through the coffered ceiling for both mechanical and natural systems with the provision for exhaust at the east wall behind the environmental veil.

Figure 6. Light Air Duct above Court Room entrance lobby.

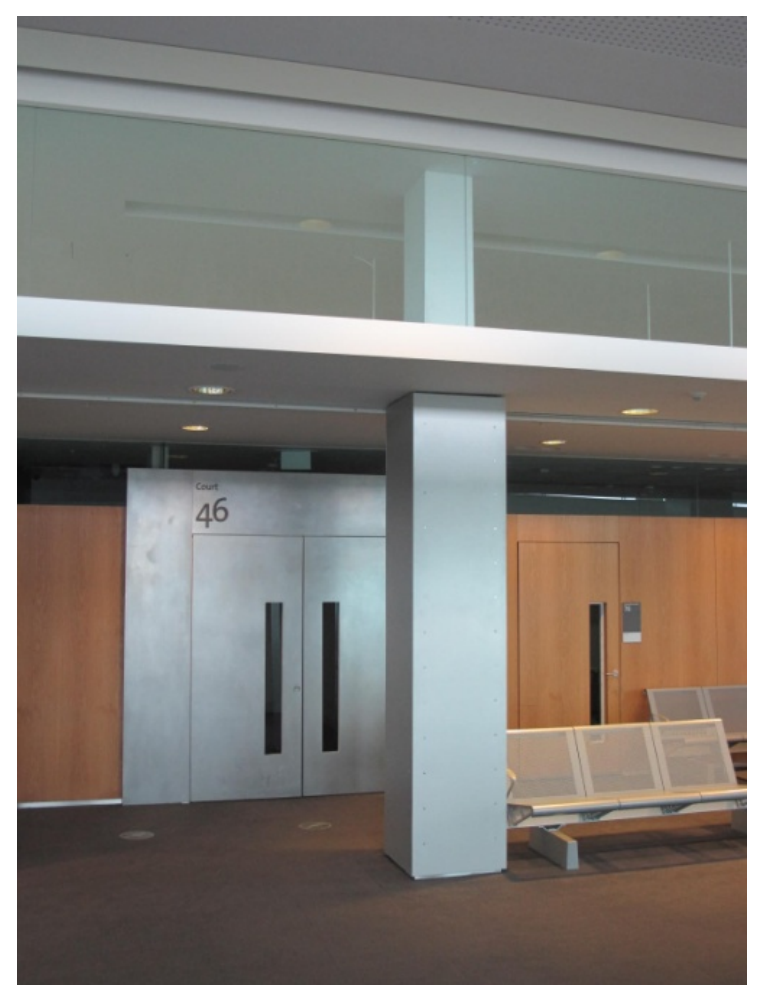


Figure 7. Light Air Duct construction assembly.

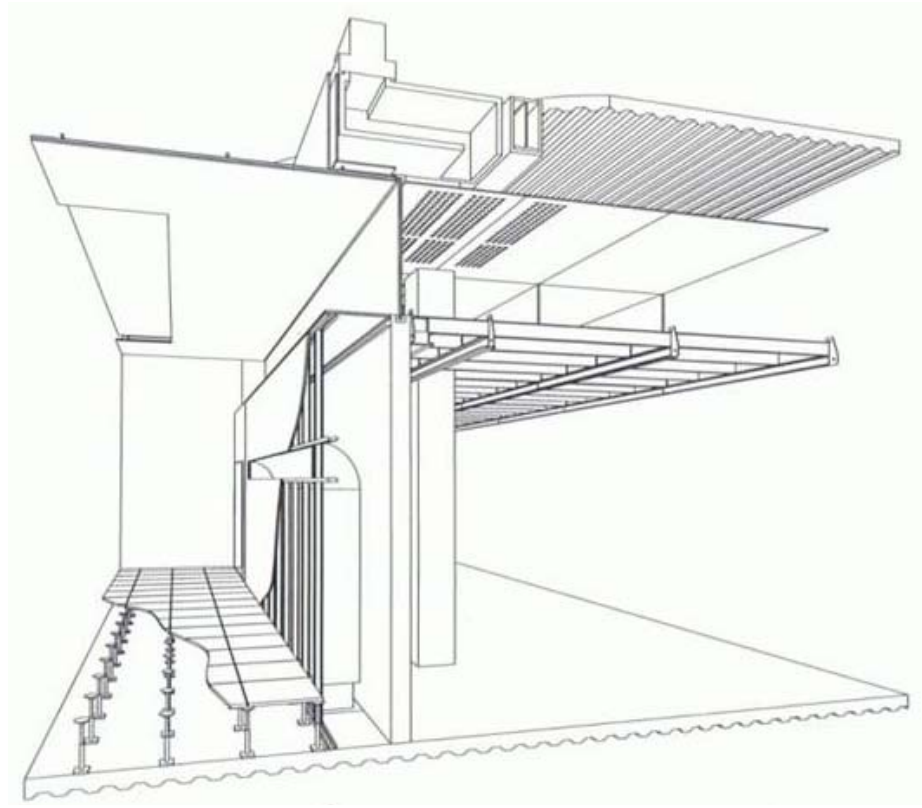

Figure 8. Light Air Duct (extract from Figure 4).

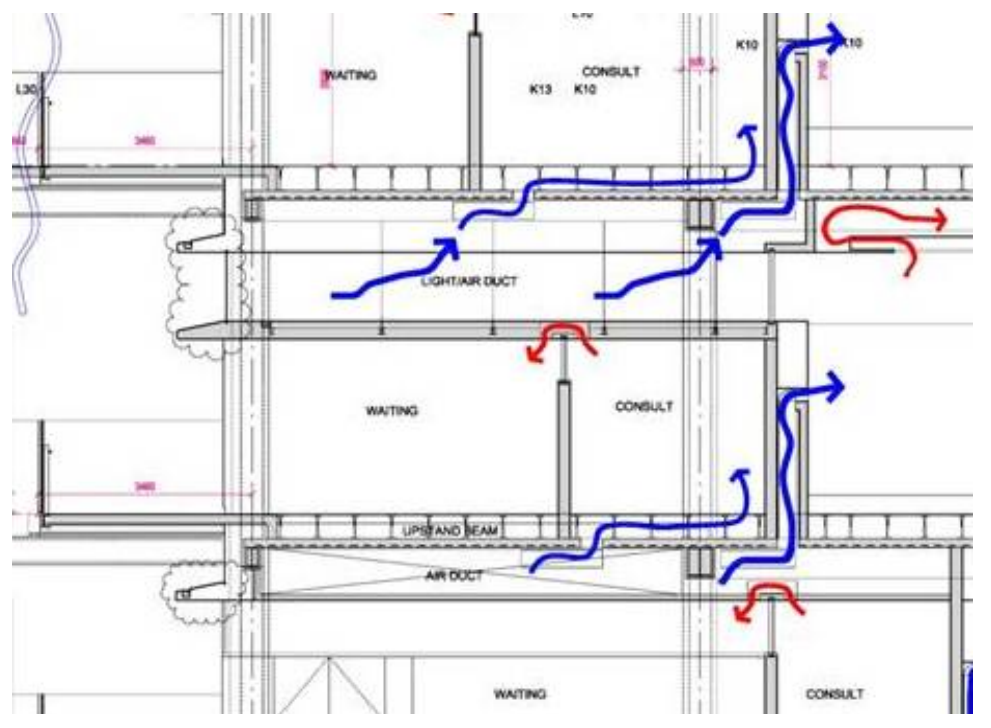

\subsection{Finger Courtrooms and Double Skin Facades}

The end "finger" courtrooms are clad in two layers, an inner layer with a low window/wall ratio with openings within a "Mondrian" patterned layout both at high level and vertical slot windows and an outer layer of large glass panels providing a protected acoustic buffer zone for the shorter air paths of the natural ventilation system for these rooms. The air inlets are in the soffits of the "fingers" and acoustic dampers are embedded in the depth of the inner wall.

\subsection{The Atrium and Its Passive Ventilation Systems}

A 10 storey high atrium is the interior feature which welcomes the visitors to the building including court room users. A cafe is sited at ground floor and waiting areas on balconies overlooking the atrium 
are provided at each court room level. The atrium environment is tempered by the ventilated double skin façade; the air inlets to this are shown in Figure 9, outlets are provided at the top of this double skin facade. Air inlets are provided to the base of the atrium itself with air outlets at the soffit of the atrium for warm air already in the interior. Comfort conditions in the waiting areas can be additionally managed through the mechanical ventilation system which has outlets in the floor void.

Figure 9. Air inlets to double skin atrium façade (foreground) on West facade with inlet grilles to Light Air Ducts (background).

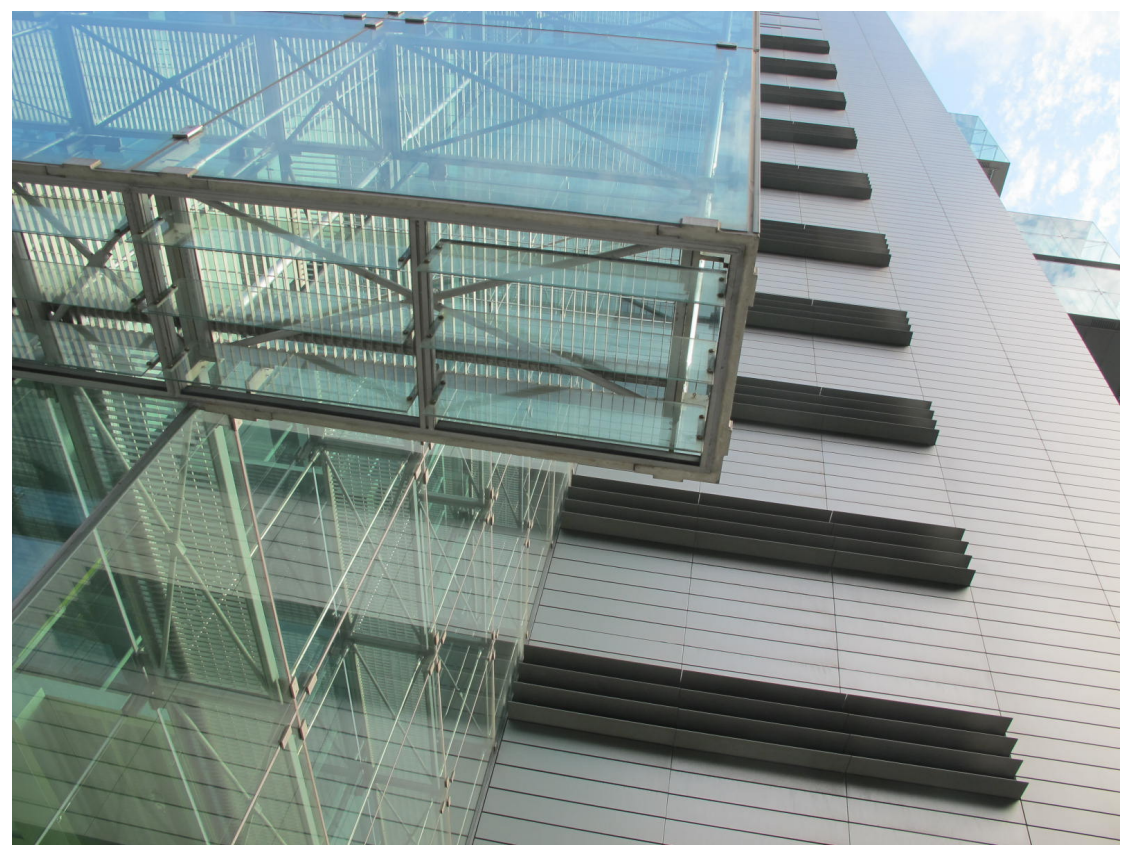

\subsection{Borehole Cooling and Thermal Wheel}

The energy load of the mechanical ventilation system is mitigated by the use of ground water cooling from the Manchester aquifer 80 metres below ground and a thermal flywheel which reclaims energy from the extract cycle of the system.

\section{The Building in Use, Systems and Spaces}

An extended commissioning period of more than three years (with origins in a commercial dispute from another project) occurred for the Building Management System following the Practical Completion of the building in 2007; it is only since early 2011 that the Court Service's local team has been managing this system in the agreed way [21]. Honeywell had installed the system and would continue to manage it after the commissioning period was signed off. However, whilst commercial difficulties were being worked through the opportunity for all parties to get to fully know the building's capabilities in conjunction with the design team was being deferred. During this earlier period energy bills had been high as mechanical and electrical systems had been typically kept on even when this had not been necessary. The Civil Justice Centre had to be fully operational and saving energy or indeed natural ventilation was not of the highest priority. 
Since the end of commissioning in 2011, Chris Hosker's role as Facilities Manager for the Ministry of Justice assumed a greater role and the default position for building systems would tend to be OFF rather than ON. Energy bills have been closer to predicted performance. The gas heating bills have for the past year been within the projected usage; however the electricity usage which includes chillers, fans and lights (as well as user equipment not subject to design prediction) remains high [22].

Honeywell, in managing the BMS, are employed by G4S Total Facilities Management ("the largest secure outsourcing company in UK and Ireland" [23]), who manage the building under the terms of the Agreement to Lease. The motorised dampers which control the movement of air through the facade and into and out of courtrooms are maintained under a contract with Colt. The facade is cleaned twice a year (not frequently and it does show somewhat) and the Building Maintenance Unit deals effectively with the cantilevered fingers and the two layers of the environmental veil. The Court Service (now Ministry of Justice) maintains a local team of which Chris Hosker is the head. Everything is accessible except for one set of dampers where the floor panels were said to be not accessible.

At the time of writing the Courts are running at $98 \%$ occupancy and no days have been lost to the service. This is impressive and this level of usage was not anticipated in the original brief.

Of the buildings many systems, both innovative and industry standard, the Facilities Manager confirmed "everything works". This, while re-assuring, didn't provide information about how well everything works. Together with the information that electricity bills remain above predicted figures, the focus for the author then became to what extent are the mechanical systems in use rather than the "natural" ones.

On the day of the visit (14 September 2012, low wind speed, some rain), the mechanical systems were much in use but no heating or cooling was being added to the system, gains and losses were being balanced by the thermal wheel. The temperatures of water from the two boreholes were $10.9{ }^{\circ} \mathrm{C}$ and $13.2{ }^{\circ} \mathrm{C}$ respectively and the temperature difference between this and $21{ }^{\circ} \mathrm{C}$ cools the building. The aquifer used to supply the local and well known Boddington's Brewery with chilled water.

\subsection{Daylight and Electric Light}

Significant effort had been made at the design stage to introduce daylight into all the principal spaces of the building and this contributes very much to the quality of the building. The light shelves within the environmental veil and above the staff corridor in particular on higher floors $(5.6 \mathrm{~m}$ floor to floor) (see Figure 10) are effective in bringing the amenity of changing light and outside awareness into the larger courtrooms. The light shelves of the internal "Light Air Ducts" are a bit more gestural from a daylighting viewpoint (see Figure 4); at design stage it was found that the number of reflections required to reach the court room had resulted in significant loss of light. Indeed a concealed row of fluorescent lamps is provided to add to the light when required. A high level of daylight is found, as predicted more at the east side of the court rooms than the west. A photograph of the lighting effect in one of the upper court rooms can be seen in Figure 11.

The smaller courtroom on lower floors ( $4.4 \mathrm{~m}$ floor to floor) abutting the atrium had a pleasing shaft of sunlight entering the rooms from high level on the occasion of the visit (see Figure 12). 
Figure 10. Section at East wall showing air extract, light shelves above corridor and in environmental veil (extract from Figure 4).

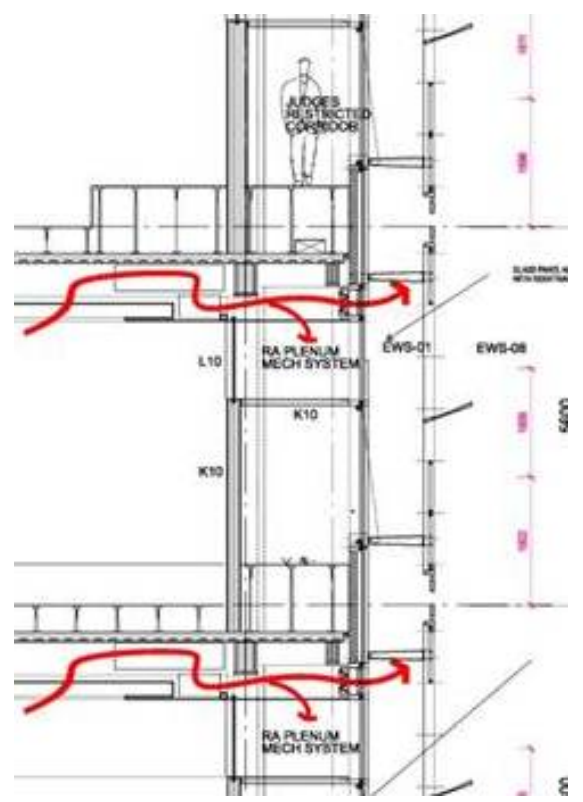

Figure 11. Upper Court Room with air slot at RHS.

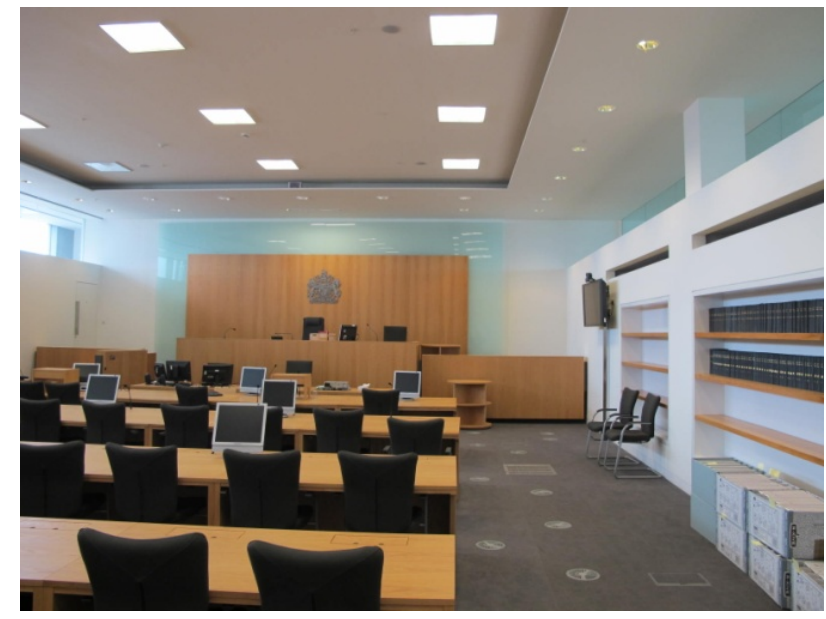

Figure 12. Lower Court Room.

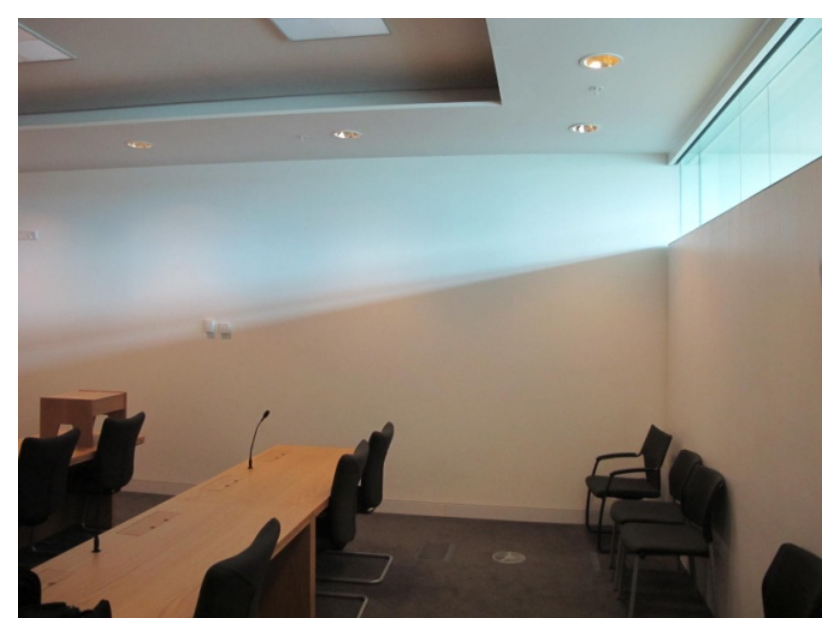


When the court rooms are in use the electric lighting is usually switched on. This helps ensure an even quality of light deep into the space suitable for consulting documents in detail.

Presence detectors (in effect movement detectors) provided had tended to switch off during court sessions as they were unable to detect sufficient movement in the room. They have been reset to operate after a four hour period without the "presence" of activity. The traditional approach to switching off lights after leaving the room empty has however proved to be generally adopted by the building's users [22].

The presence of daylight in the court rooms does not seem to a be substitute for electric light, however a pleasing change of light and external awareness is an important compliment to what are otherwise internal rooms.

\subsection{Mixed Mode Ventilation (Court Rooms, Consultation Rooms and Waiting Areas)}

It is in the management of the ventilation system that the tension between energy performance and user comfort and preferences is more noticeably played out. The building users (the judges are the most influential) have insisted on high levels of comfort and these demands have been met as a priority.

In order to "manage" the building and it's users temperature settings for court rooms are controlled centrally, set at $21^{\circ} \mathrm{C}$ with a $+/-2{ }^{\circ} \mathrm{C}$ allowance for local control within the court room. CIBSE Good practice guidelines for natural ventilation propose that summertime temperatures can be allowed to rise somewhat if sufficient air movement and fresh air are provided, this is not allowed for at present in the management of the courtroom spaces [24]. The guidelines further discuss a relaxation of clothing in warm summer conditions to help with the temperature rise; this advice counters the formality of courtroom activity [25].

In cooling mode a preference has been voiced by the users for the experience of cooling air to be felt, and this is achieved better by the mechanical system with its floor based air supply. Accordingly in natural ventilation mode, a degree of mechanical supply air is provided through the floor outlets to satisfy this desire. This is described in the CIBSE guidelines as concurrent mixed mode; the other term used there is changeover mixed mode, which is in operation in mid season [26].

The natural ventilation supply air is delivered at chest level from slots in the inner wall (see Figure 8); this was in order to reduce the discomfort of using experiencing draughts in winter and mid season when this air would be cooler [21]. This has advantages also in not disturbing papers on desks. It may be that provision of additional lower outlets for summertime operation would have been more advantageous.

The natural ventilation system for these areas as analysed at design stage is a "wind driven system" and is not reliant predominantly on stack effect [21]. The Building Management System has been set to operate the natural ventilation system at a defined wind speeds and directions. It does not operate when it is raining, although fins at the air entries should prevent rain entering except in driving rain conditions. It has not been ascertained whether the settings reflect a risk-averse management view or whether they have been reached through a process of trial and error.

Night time cooling by the natural ventilation system has not yet been carried out; it was agreed that an opportunity to save energy is being missed at present [22]; it may be that the services management 
team may be reluctant to adjust settings which are working satisfactorily at present and energy performance may not currently be one of the higher management priorities. It should be noted that at design stage the option for a concrete structure was discussed and rejected by the Client and Project Management team. This would have provided additional thermal capacity to smooth out temperature swings over the daily cycle.

The Facilities Management team appears not to have yet fully exploited the low energy potential of the building. The current team has not yet seen the building through a hot summer; this may provide an opportunity to put the natural ventilation system to more use.

A more detailed commentary on the performance of this aspect of the building could be made with more information on the percentage time the building is heating/cooling modes and natural/ mechanical modes (predicted to be $40 \%$ natural at design stage). Variation of court room performance due to size/height and position within the building (the north air inlets are less exposed to the South west prevailing wind) is of particular interest. This information has been requested but has not been forthcoming at the time of writing. It is, however, in those parts of the building which are more prototypical or innovative that the greatest benefits of a Post-occupancy evaluation could be had, for the Client (both the public and the private elements of the client body), the Design Team and for the industry generally.

\subsection{Judge's Retiring Suites}

These hotel-like rooms are planned with radiators and opening windows and without mechanical ventilation. The top hung windows have restricted stays and discrete guarding panels for safety. There is a tendency for Judges to leave these windows open at the end of the day, giving additional work for the FM team. Some judges have stated that they would have preferred air conditioning in their offices [22].

\subsection{Atrium and Waiting Areas}

These areas are well served by the Passive Ventilation systems and back up comfort cooling in preventing overheating in summer. Ushers who populate reception desks on the edge of the waiting area balconies were cold in winter and this became a local news story reflecting badly on the project [27]. Subsequently discrete glass cabins have been provided for them without unduly clashing with the refined detailing of the concourse areas. The mechanical ventilation further inboard on the balcony areas may however be enough to keep waiting Courtroom users comfortable on a chilly Manchester day, especially if they have kept their coats with them.

\subsection{Flexibility for Change}

The building is currently intensively used with pressure for more intense use in the future as the legal climate changes (legal aid is being withdrawn for divorce, children's cases are becoming more frequent and the future of court buildings in outer areas of Manchester are being reviewed). 
The Advocates Area has successfully been converted to a training area (saving money on Hotel Conference facilities) and churn of office spaces from lower floors to upper floors is part of the life of the building.

More problematic is the desire for a greater proportion of smaller court rooms than the current mix of large and small for which the building was designed as the opportunity to rationalize court services in Greater Manchester is being examined.

\section{Building Performance}

The building is performing well in terms of serving its users and the functions of the Court Service in many ways. It does not yet appear to be doing this with the very low energy performance for which it was designed. The higher than predicted electricity bills indicate that the mechanical system is more frequently on than was predicted.

The structure and fabric of the building has been built well and is in good condition; the Client had appointed Gartners in Germany (part of the Permasteelisa group) to develop the detail of the facade and to construct it, integrating grilles, dampers and actuators under their overall scope of work. Strict performance criteria had been laid down in the Specification, the detail of which was negotiated with Gartners. Mock ups had been made, inspected and signed off. A high degree of quality control was sought and achieved.

The borehole cooling and the heat recovery system (thermal wheel) are considered effective in reducing energy consumption [22].

The missing link in environmental performance appears to be the under use of the natural ventilation system and over use of the mechanical system.

Public Buildings larger than $1000 \mathrm{~m}^{2}$ in area in the United Kingdom are required to Display an Energy Performance Certificate prominently in the interior. The Certificate displayed in the entrance hall of MCJC indicates a $\mathrm{C}$ rating, well above average for this type of building. In parallel with the previous EPC (rating D) in 2009 an Advisory Report was produced with a number of recommendations [28]. These are in the main of a general nature relating to good housekeeping, in particular of electrical equipment and computers. An observation regarding windows left open relates to mechanical cooling, it is not clear to which area of the building this relates. The value of the DEC system and its Advisory Reports is reviewed in an MSc Dissertation by Henderson [29].

However it seems logical that a BREEAM "Excellent" building should be achieving a higher rating than "C". The Facilities Manager is of the opinion that this performance can be raised to " $\mathrm{B}$ " with a bit more experimentation and effort. He believes that the performance has not yet reached the potential that the building offers. In particular he noted that night time cooling using the natural ventilation system has not yet been trialed. The FM team appears to be incrementally testing the degree to which the natural ventilation system can be used without the users being aware of this [22]. A relaxation of the strict temperature bands could help in this direction. Carbon emissions could be reduced substantially by sourcing electricity from a renewable supplier.

As a comparison the most recent Display Energy Certificates of a number of buildings mentioned earlier, four Court buildings and two other prominent government building were obtained and the results are tabulated below (see Table 1) [28]. 
Table 1. Comparison of Display Energy Certificates.

\begin{tabular}{|c|c|c|c|c|c|c|c|}
\hline Building name & $\begin{array}{c}\text { Date } \\
\text { completed }\end{array}$ & $\begin{array}{c}\text { Environmental } \\
\text { systems adopted }\end{array}$ & $\begin{array}{l}\text { Energy } \\
\text { rating }\end{array}$ & $\begin{array}{c}\text { Annual energy usage } \\
\left(\mathrm{KWh} / \mathrm{m}^{2} / \mathbf{y r}\right) \\
\text { (Heating/Electricity) }\end{array}$ & $\begin{array}{l}\text { Area } \\
\left(\mathbf{m}^{2}\right)\end{array}$ & $\begin{array}{c}\text { Building } \\
\text { emission rate } \\
\mathrm{Kg} / \mathrm{CO}_{2} / \mathbf{m}^{2} / \mathbf{y r}\end{array}$ & Architect \\
\hline $\begin{array}{l}\text { Lanchester } \\
\text { Library, } \\
\text { Coventry }\end{array}$ & 2000 & $\begin{array}{l}\text { Natural ventilation, } \\
\text { stack effect, daylight }\end{array}$ & $\mathrm{D}(89)$ & $285 / 64$ & 11812 & 84.6 & $\begin{array}{l}\text { Short and } \\
\text { Associates }\end{array}$ \\
\hline $\begin{array}{c}\text { Home Office, } 2 \\
\text { Marsham Street, } \\
\text { London }\end{array}$ & 2005 & $\begin{array}{l}\text { Air conditioning, heat } \\
\text { recovery }\end{array}$ & E (112) & $25 / 129$ & 68797 & 87.2 & Farrells \\
\hline $\begin{array}{l}\text { Manchester Civil } \\
\text { Justice Centre }\end{array}$ & 2007 & $\begin{array}{c}\text { Mixed mode } \\
\text { ventilation, daylight, } \\
\text { borehole cooling }\end{array}$ & $\mathrm{C}(69)$ & $59 / 78$ & 35348 & 49.8 & $\begin{array}{c}\text { Denton Corker } \\
\text { Marshall }\end{array}$ \\
\hline $\begin{array}{c}\text { Manchester } \\
\text { Magistrates } \\
\text { Court } \\
\end{array}$ & 2001 & -- & $\mathrm{F}(135)$ & $150 / 140$ & 12077 & 82.8 & Gensler \\
\hline $\begin{array}{l}\text { Parliamentary } \\
\text { Offices, Bridge } \\
\text { Street, London }\end{array}$ & 2001 & $\begin{array}{c}\text { Displacement } \\
\text { ventilation, thermal } \\
\text { mass, heat recovery } \\
\text { light shelves }\end{array}$ & E (120) & $62 / 171$ & 18098 & 99.5 & $\begin{array}{l}\text { Hopkins } \\
\text { Architects }\end{array}$ \\
\hline $\begin{array}{l}\text { Rotherham } \\
\text { Magistrates } \\
\text { Court }\end{array}$ & 1994 & $\begin{array}{c}\text { Displacement } \\
\text { ventilation, heat } \\
\text { recovery, mixed } \\
\text { mode vent }\end{array}$ & $\mathrm{C}(64)$ & $55 / 69$ & 5368 & 46.0 & $\begin{array}{c}\text { Rotherham BC } \\
\text { Architects }\end{array}$ \\
\hline $\begin{array}{c}\text { Truro Crown } \\
\text { Court }\end{array}$ & 1990 & Natural ventilation & $\mathrm{C}(75)$ & $93 / 71$ & 3645 & 57.3 & $\begin{array}{c}\text { Evans and } \\
\text { Shalev }\end{array}$ \\
\hline $\begin{array}{c}\text { Westminster } \\
\text { Magistrates } \\
\text { Court }\end{array}$ & 2011 & $\begin{array}{l}\text { Natural ventilation, } \\
\text { stack effect, daylight }\end{array}$ & $C(60)$ & -- & 8466 & 26.9 & Hurd Rolland \\
\hline
\end{tabular}

In the Westminster Magistrates Court Energy Performance Certificate (a different format and data set from the DEC's) a benchmark for the energy rating is quoted as "Buildings similar to this one could have ratings as follows: 43 if newly built, 114 if typical of existing stock". The DECs indicate that a numerical Energy Rating of 100 is considered "average" for that type of building. In viewing these certificates it can be seen that improvements and (in one case) setbacks in performance can occur over time.

It can be seen that Manchester Civil Justice Centre performs well in this comparison.

Reactions from Building Users and the Public have been predominantly favorable with many people admiring the building [22].

\section{Managing the Building: User Satisfaction and Reducing Carbon Emissions}

Operating costs are frequently given priority in Post Occupancy Studies; however this should be kept in the context of the economic priorities of managing a business or an organisation. Baird highlights "the 1:10:100 ratio of: operating costs: combined capital and rental costs: total salary costs 
of occupants ... makes it abundantly clear where the attention should be centred" [10]. Well performing buildings whether "green" or less so should help improve staff efficiency, morale and well being and hence productivity; frequently the "green features" of a building do this (by improvement in air quality, daylight and the perception of user control) alongside lowering energy costs and carbon emissions.

The Building Managers' at Manchester Civil Justice Centre initially prioritized occupant satisfaction at the expense of high operating costs. Step by step they are satisfying occupants whilst also reducing energy costs and carbon emissions, finding that the two need not be in opposition to each other.

In approaching this study the author was keen to obtain energy consumption data and statistics of user satisfaction and analyze this, detail of this has been requested but unfortunately not been made available; however the relation between the two evaluation criteria is of particular interest in a mixed mode building. Chris Hosker explained the Facilities Management team's priorities in meeting the expectations of his demanding clientele and the evolution of the approach to managing the building. This insight is as valuable as the confirmation of performance or satisfaction as these factors can vary over time.

Chris Hosker, as Facilities Manager, has got to know the building well and understands the way the building can perform. There has been a significant turnover of engineers at Honeywell (who are employed as part of the building management services provided under the Agreement to Lease) assigned to this building and Chris has held the continuity of knowledge to help the new engineers adjust to their roles. A new engineering culture for managing mixed mode buildings is required to more closely follow the ups and downs of daily, weekly and seasonal weather and occupancy patterns with settings for the building systems. The initiative for this new culture may be inhibited somewhat by the separate interests of landlord and leaseholder under the Private Finance Initiative. Chris Hosker is approaching retirement and is due to write a guide to running the building for the next person to hold his position. It is hoped that the same level of understanding and commitment to keeping both building users comfortable and energy bills down together with an openness to outside scrutiny can be found in his replacement.

The building is managed centrally with a limited degree of local override possible; little risk is taken with allowing for internal temperature variation over the seasons. For this reason occupant satisfaction is a less helpful test of the 'success' of the building than if occupants were free to adjust the ventilation system fully themselves and could comment on the usability of the local control systems.

This review has explored the inter relationship of building management, occupant activity and energy performance in a complex bespoke building. The expectation (and the current agreement between occupants and building managers) is that the conditions within the courtrooms should be kept within a narrow temperature band. The idea (favoured by low energy design thinking) that in summer temperatures could rise while compensated by the passage of a stream of fresh air (as in traditional buildings) is not currently being adopted in this building. The maintenance of a narrow temperature band presupposes that varying clothing over the seasons is not to be considered in a court room.

The building, its services systems and its occupants form a dynamic system with several variables and which can change over the years as well as according to its regular patterns by day, week, by 
season. Post-occupancy studies and reviews like this provide a partial view of this system; in this case to see opportunities to reduce energy consumption closer to predicted figures and to identify sticking points which are preventing this from happening at present.

As energy costs rise and if temperatures rise significantly the mixed mode ventilation system allows for different priorities in the future; the building is future proofed.

\section{Conclusions and Lessons for Other Projects}

Manchester Civil Justice Centre is a landmark building but it is not an icon. It is a rigorous and sophisticated response to a demanding brief and represents a thoughtful effort in bringing together environmental and architectural ambitions. The more visible environmental features for daylight on add more value than energy reduction; they contribute to the amenity of the building and the health and productivity of the building's users. The natural ventilation system, when in use, will similarly contribute to health and productivity. The contribution of these features (with electric lights mostly on and natural ventilation less used than it could be) to the reduction of the energy consumption at present appears less than the writer was hoping for and less than predicted at design stage.

Building a significant building is the work of and of consequence to many different stakeholders; a few tentative conclusions of this paper are listed below according which apply to some of the more significant ones: Client bodies, Users and the Design Team.

Making a brief is a bold step by or on behalf of a Client (by Feilden and Mawson and Mouchel in this case); this has been a strong foundation for a good project. Predicting usage and demand is an art and not a science; circumstances will change over time. "Long life, loose fit, low energy" as promoted by Alex Gordon is a good slogan for many building types but hard to apply for a specialist field such as the Court Service [30]. The balance of large and small court room sizes will always be hard to predict.

The brief for seven different courtroom sizes is matched by a significant variation of the floor layouts; ventilation air is routed in ceilings below the floor served leading to complex layouts of light and air ducts, these being architectural constructions rather than metal ducting. The environmental systems have not led the design as in some low energy buildings; they provide a supportive role and are embedded discretely within the design of the building both externally and internally. Since the building was conceived new developments in Building Information Modelling (BIM) would significantly help in documenting and understanding the light air ducts and raising their visibility within the design and construction process.

The positioning of fresh air inlets at chest level within the court rooms level may have reduced the extent of the system being used. An additional lower position for summertime use could result in an additional stack effect across the court room. The performance of buildings in use is not an accurate science with many variables such as occupancy and user preferences. BMS systems can provide a user friendly interface for visualizing and operating the buildings controls, the design of these could be the basis of earlier discussions between designers and building managers (if appointed) at design stage.

The Facilities Management team could be bolder in using the natural ventilation system, for night time cooling and with more fresh air and a greater tolerance of warmer temperatures in summer. The 
Users should be engaged in discussion about this to see whether together a reduction of energy could be achieved.

The Private Finance Initiative and Public Private Partnerships in general tend to prioritise the commercial agreement at the expense of detailed user involvement in the procurement process. The users are remote not only from the design process but also the management processes once the building is in use. This leads to a standardised approach to user comfort and a preference for central control (which is possible with a mixed mode system). Clients who are able to access finance directly and commission their own building are in a stronger position to involve the building users at design stage and during occupancy; this should allow for a greater ownership of the low energy agenda throughout the building and help improve energy performance. Those Public Sector Clients involved in PFI/PPP arrangements have ceded much of the control over the costs of services provided to them (especially in long term agreements) to the private sector.

The pursuit of sustainability and low carbon design in particular exists in a cultural, political and commercial context of multiple stakeholders of different priorities. The investigation of this building post- occupancy has come across different lessons than those which were perhaps expected.

The complexity of the Lease agreement including the provision of building management services mitigates against an open information culture which could be more supportive of research such as this, which could enable improvement in energy performance in an individual building but also the sharing of knowledge about design of natural ventilation systems, their operation and performance, which is not sufficiently well tested in practice.

There is a need for a wider dissemination of low energy design within the commercial development industry in particular. The design of Manchester Civil Justice Centre is an important step in that direction and its lessons should be studied in more detail. Even if its performance to date is not as predicted, the building is future proofed; as energy costs rise, a different trade-off between maintaining strict temperature bands can be relaxed and a greater use of natural ventilation can be adopted.

The building is working well in keeping its users comfortable; it also appears to be performing well enough to withstand a more detailed scrutiny of its performance and its environmental systems than this study has been able to. This more detailed evaluation would help encourage an improvement in energy performance and a valuable sharing of knowledge across an industry which struggles to learn from its own experience.

A Post-occupancy evaluation is not a panacea for all environmental design ills, however in the case of a major building with a significant number of innovative features it is valuable for improving the performance of the building, ongoing building commissioning, feedback to the Design Team and knowledge sharing within the industry. How will these benefits be paid for and how will any risks be managed in a fragmented industry?

\section{Acknowledgments}

The experience of working on the project with all the team at Denton Corker Marshall (Melbourne and London), with consultants at Connell Mott MacDonald (now Mott MacDonald), and contactors at Bovis Lendlease in particular has been both a valuable part of my career and enjoyable experience. 
Thank you to Chris Hosker at Manchester Civil Justice Centre for providing the feedback to the project and the insight that the handover of the building is just the beginning of the building's life.

\section{References}

1. Wikipedia. Manchester Civil Justice Centre. Available online: http://en.wikipedia.org/wiki/ Manchester_Civil_Justice_Centre (accessed on 21 November 2012).

2. Best British Buildings of the 21st Century-X. Blueprint, 14 January 2011; Available online: http://www.blueprintmagazine.co.uk/index.php/everything-else/best-british-buildings-of-the-21stcentury-x/ (accessed on 21 November 2012).

3. Baird, G. Sustainable Buildings in Practice: What the Users Think, 1st ed.; Routledge: New York, NY, USA, 2010; pp. 93-101.

4. Krausse, B.; Cook, M.; Lomas, K. Environmental Performance of a Naturally Ventilated City Library; De Montford University: Leicester, UK, 2006.

5. Bordass, W.; Leaman, A.; Eley, J.; A Guide to Feedback and Post Occupancy Evaluation; The Usable Buildings Trust: Bootham, UK, 2013. Available online: http://www.usablebuildings.co.uk/ (accessed on 9 April 2013).

6. Zimmerman, A.; Martin, M. Post-occupancy evaluation; benefits and barriers. Build. Res. Inf. 2001, 29, 168-174.

7. Hadjri, K.; Crozier, C. Post-occupancy evaluation; purpose, benefits and barriers. Facilities 2009, 27, 21-33.

8. Riley, M.; Moody, C.; Pitt, M. A Review of the Evolution of Post-Occupancy Evaluation as a Viable Performance Measurement Tool; Liverpool John Moore's University: Liverpool, UK, 2009.

9. Brand, S. How Buildings Learn, What Happens after They are Built; Penguin Books: Phoenix, AZ, USA, 1994.

10. Baird, G. Sustainable Buildings in Practice: What the Users Think, 1st ed.; Routledge: New York, NY, USA, 2010; pp. 1-3.

11. Baird, G. Sustainable Buildings in Practice: What the Users Think, 1st ed.; Routledge: New York, NY, USA, 2010.

12. Duffy, F.; Hannay, P. The Changing Workplace; Phaidon: London, UK, 1992.

13. Etheridge, D.W.; Ford, B. Natural Ventilation of Tall Buildings, Options and Limitations; School of the Built Environment, Nottingham University: Nottingham, UK, 2008; p. 6.

14. Poirazis, H.H. Double Skin Facades for Office Buildings, Literature Review; University of Lund: Lund, Sweden, 2004.

15. Burry, J.; Burry, M. The New Mathematics of Architecture; Thames and Hudson: London, UK, 2010; pp. 142-147.

16. Usable Buildings Trust. Available online: http://www.usablebuildings.co.uk/ (accessed on 21 November 2012).

17. Rogers Stirk Harbour. Available online: http://www.rsh-p.com/rshp_home (accessed on 21 November 2012).

18. Hopkins Architects. Available online: http://www.hopkins.co.uk (accessed on 21 November 2012).

19. FCB Studios. Available online: http://www.fcbstudios.com (accessed on 21 November 2012). 
20. David Chipperfeld Architects. Available online: http://www.davidchipperfield.co.uk/ (accessed on 21 November 2012).

21. Facer, M. Mott MacDonald Ltd., London, UK. Personal communication, November 2011.

22. Hosker, C. Manchester Civil Justice Centre (MCJC), Manchester, UK. Personal communication, 14 September 2012.

23. G4S. Who We Are. Available online: http://www.g4s.uk.com/en-GB/Who\%20we\%20are/ (accessed on March 2013).

24. Chartered Institution of Building Services Engineers (CIBSE). CIBSE Applications Manual AM10 Natural Ventilation in Non-Domestic Buildings; CIBSE: London, UK, 2005.

25. CIBSE. CIBSE Applications Manual AM10 Natural Ventilation in Non-Domestic Buildings; CIBSE: London, UK, 2005; p. 6.

26. CIBSE. CIBSE Applications Manual AM10 Natural Ventilation in Non-Domestic Buildings; CIBSE: London, UK, 2005; p. 8.

27. Staff at award winning Civil Justice Centre offered fleeces because of the cold. Manchester Evening News, 22 January 2011; Available online: http://menmedia.co.uk/manchestereveningnews/ news/s/1406033 (accessed on November 2012).

28. Non Domestic Energy Performance Register. (with Post Code or Ref No from Energy Performance Certificate). Available online: https://www.ndepcregister.com/ (accessed on 20 November 2012).

29. Henderson, V. An Evaluation of Display Energy Certificates as a Policy Initiative to Improve Energy Efficiency within Public Buildings in Cornwall. Master Thesis, Climate Change and Sustainable Development, De Montford University: Leicester, UK, 2011.

30. Gordon, A. Architects and resource conservation: The long life, loose fit low energy study. RIBA J. 1974, January, 9-12.

(C) 2013 by the authors; licensee MDPI, Basel, Switzerland. This article is an open access article distributed under the terms and conditions of the Creative Commons Attribution license (http://creativecommons.org/licenses/by/3.0/). 